\title{
Remembering Frederick Zeuner and others at the Institute of Archaeology, 1945-48 Grace Simpson
}

Grace Simpson (Fig. 1) was one of the small group of students who enrolled at the Institute, which was then housed in St John's Lodge in Regent's Park, when teaching re-started after the Second World War. She fondly recalls those days, when she was taught by Kathleen Kenyon, Gordon Childe, Stuart Piggott and, most memorably, Frederick Zeuner.

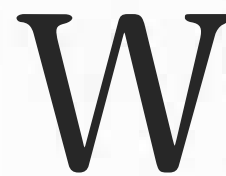

hen I was about eight years of age, my father, F. Gerald Simpson, took me to hear a lecture by Sir Flinders Petrie at Newcastle Upon Tyne. They knew each other through their excavations and discoveries, Petrie from his extensiveresearch in Egypt and my father through his naming of Hadrian's Wall. ${ }^{1}$ I remember putting my small hand in Petrie's and looking up what seemed a long way into his eyes - a memory of long ago that I cherish.

Kate Hodgson was one of my father's colleagues for work in Cumberland, ${ }^{2}$ and her accounts of digging with Mortimer Wheeler at Maiden Castle, and of his lectures in London before the Second World War, fired my wish to attend courses at the Institute of Archaeology as soon as it could be re-opened. In September 1945 came news that courses were to commence in October and I hurried to London, was interviewed, paid a fee of two guineas (£2.10) in lieu of London University Matriculation, and I was in!

Six students attended the evening lectures, which were given by Kathleen Kenyon on the European Early Iron Age and by Frederick Zeuner (Fig. 2) on environmental archaeology. Miss Kenyon's reading lists for essays included German, French, Spanish and Czech works. I guess that my fellow students found these as complex and hard to cope with as I did, and the stress that they caused me is not forgotten. But she was always supportive and helpful.

Professor Zeuner's reading list contained a book entitled Teach yourself to think - an example of his kindly humour. Whenever I try to write something, as now, the memory of what happened to my first essay for him returns to me. Every clause in each sentence was discussed. He, who had come to Britain as a refugee in 1933, knew far better than I how to express thoughts clearly in English. All his students knew that he was concerned for our progress and we were devoted to him. His lectures were always enjoyable and I still possess my notebook with course subjects on soils, minerals, fossils indicative of climate, and so on, which might seem dreary but which we all found fascinating. He had already published The Pleistocene period in 1945 and I eagerly bought his next book,
Dating the past, on 26 June 1946, two months after it was published. ${ }^{3}$ It is subtitled An introduction to geochronology, for his aim was to correlate various natural sciences in relation to the study of man. ${ }^{4}$ The book reached a fourth edition in 1958. Calculations on changes in solar radiation in the geological record, and the then still controversial subject of continental drift, are two important topics discussed in the first edition.

Notes from Zeuner's lectures on Old Stone Age flora and fauna, and their domestication, fill a large part of one of my notebooks. Nancy Sandars described in a recent letter to me how she remembers "a lecture on domestication of animals when he showed a slide of a fine, lithe, lean wild pig and after it a heavy, rolling-in-fat, snub-nosed domestic pig and beside it its overweight snub-nosed owner - so very alike". ${ }^{5}$ He liked to see us squirm with horror when he explained the probable use of a flint handaxe as a grubbing tool for Old Stone Age man's way of obtaining his meat and veg, or "earthworms and wild carrots" as he preferred to describe it. Rachel Maxwell-Hyslop also recollects how "I used to ask him to help me with the archaeological German I could not understand. His comments were always illuminating and good value". ${ }^{6}$ My last tutorial with him was at the London Zoo, only a short way north of the Institute, where we saw the first panda that had newly arrived in Britain from China. When I was in London a few months before Zeuner's sudden death at the age of 58 on 5 November 1963, I was able to thank him for all his help. His death was a sad shock.

In 1946 Stuart Piggott was our lecturer on the Neolithic and Bronze Ages, when news came that he had been appointed to the Abercromby Chair of Archaeology at the University of Edinburgh, to succeed Gordon Childe, who had just been appointed as the first Professor of Prehistoric European Archaeology in the University of London and Director of the Institute of Archaeology. Piggott was appointed before obtaining his first degree, a BLitt at Oxford University. He was an excellent lecturer, and I particularly recall one lecture about the Danish Bronze Age that inspired me to write a sonnet.

In Gordon Childe's inaugural lecture at the Institute he asserted that "Archaeology

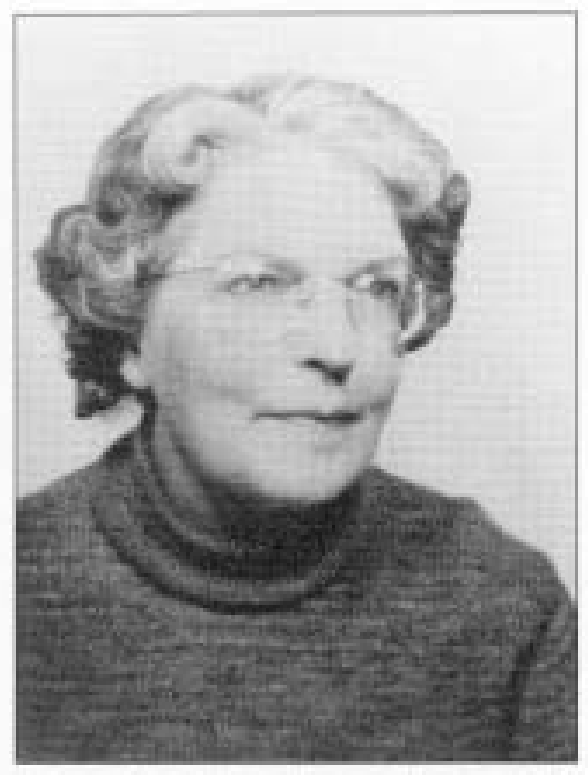

Figure 1 Grace Simpson, November 1976.

is . . . a classificatory science".? Quite true, but I had never thought of it that way. Mortimer Wheeler's view is well known: "the archaeological excavator is not digging up things, he is digging up people". ${ }^{8}$ At that time Wheeler was still setting up India's archaeology service and did not return to the Institute he had founded until the summer of 1948 .

I once experienced Gordon Childe's style of driving; fortunately there were few other cars in London then. In his very old car, driving from the Institute at St John's Lodge on Regent's Park's Inner Circle, we were lucky to reach Upper Baker Street. He approached each central island on the wrong side and then quickly wrenched the wheel in order to re-enter the left-hand lane. The last time I saw him was in a museum in Cambridge when he gave me his genial smile and a wave across the intervening showcases.

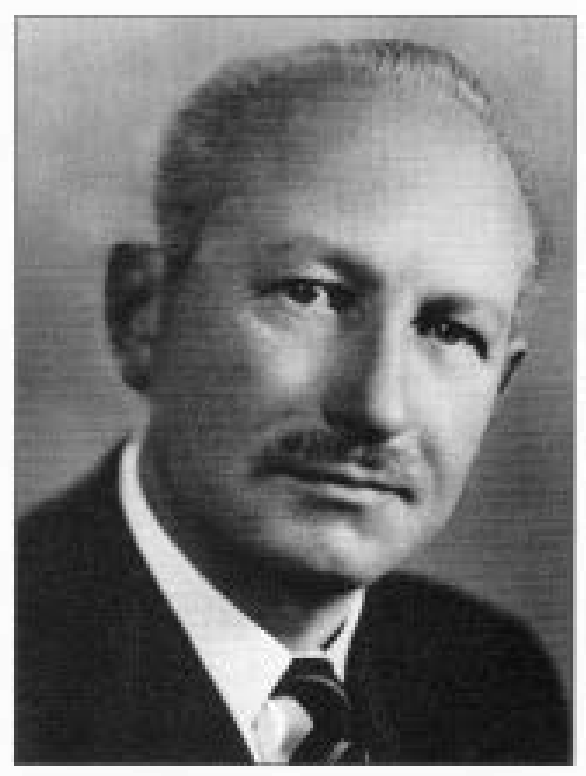

Figure 2 Frederick Zeuner, c. 1955. 


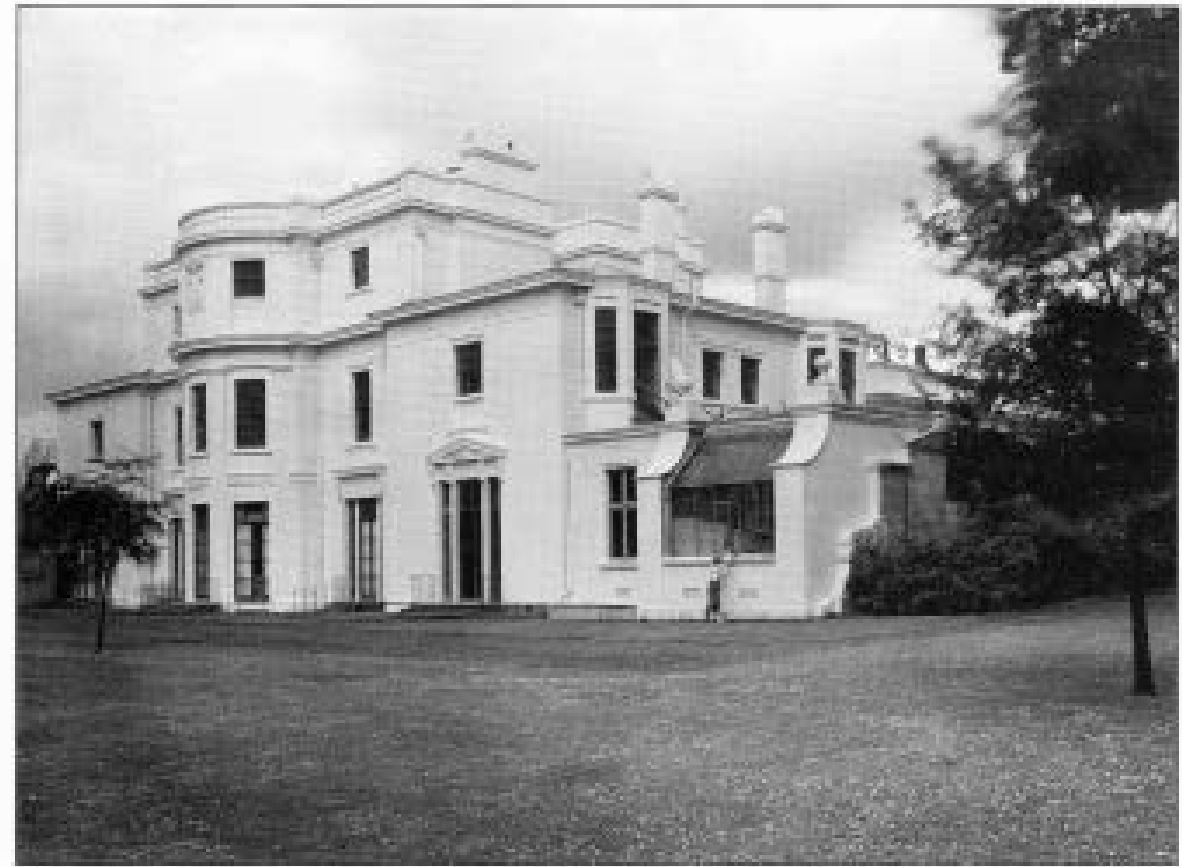

Figure 3 The west front of St John's Lodge, Regent's Park, June 1936 (the year before the building was formally opened as the Institute of Archaeology).

Walking across Regent's Park to the Institute in the evening, in a pea-souper fog, was scary. If one's feet had strayed off the path, one would soon have been lost on the huge area of grass. It was better to take sandwiches, spend the day in the Institute Library and walk together in a group back to Marylebone Road. The sandwiches were eaten in the pleasant company of the staff and any visitors who happened to be there. I remember once sitting beside the Egyptologist Dr Margaret Murray, then approaching her hundredth year. We were all, including our teachers, so enthusiastic. One day I was reading in the library when Professor Max Mallowan dashed in. He placed a large ladder against some book shelves and rushed to the top. Before he gripped a book, there was a dreadful sliding noise, and the ladder fell, with him on top of it. Students picked him up. Brushing them aside, he again mounted the ladder and took out a book. We did not see him for some weeks after that.

A fellow student, Mrs Myfanwy Rodnight, attended lectures until she fell victim to polio in the serious outbreak of 1947 and had to spend a year in an iron lung. Crippled, but a devoted subscriber to the Institute's Bulletin, she was still committed to archaeology and was trying to save an ancient feature in Streatham High Road (Roman Stane Street) shortly before her death in 1997.

I spent nearly three years at the Institute (Fig. 3). I had to be at home for almost a whole term because of family health problems during the terrible winter of January to March 1947 in the north of England, when food supplies were even more restricted than during the Second World War. Three of us took the examinations in
1948. Edward Pyddoke (who later became the Institute's Secretary) and I received the postgraduate diploma in European archaeology, ${ }^{9}$ while Michael Maitland Muller (FSA in 1976, and Emeritus Fellow of the Museums Association) received his BA. I did not obtain a degree until 1960 when I was awarded a DPhil at Oxford for a thesis on Roman archaeology, but that is another story. ${ }^{10}$

\section{Notes}

1. F. Gerald Simpson, with his colleague John P. Gibson, resolved a longstanding controversy about which emperor, Septimus Severus or Hadrian, was responsible for the building of the wall. See J. P. Gibson \& F. G. Simpson, "The Milecastle of the Wall of Hadrian at Poltross Burn", Transactions of the Cumberland and Westmorland Antiquarian and Archaeological Society 11, 390-461, 1911; and F. G. Simpson, "Excavations on the line of the Roman Wall in Cumberland during the years 1909-1912", Transactions of the Cumberland and Westmorland Antiquarian and Archaeological Society 13, 297397, 1913.

2. K. S. Hodgson was President of the Cumberland and Westmorland Antiquarian and Archaeological Society from 1948 to 1951.

3. The Pleistocene period was first published by the Ray Society in a limited edition in 1945, and secondly by Hutchinson in 1959. The four editions of Dating the past were published by Methuen in 1946, 1950, 1952 and 1958.

4. It is worth recalling that Zeuner deliberately treated the geological evidence and itsarchaeologicalimplications separately in these two books, which were intended to complement each other. Both books had a profound influence on subsequent work in Quaternary science and prehis- toric archaeology.

5. Letter dated 6 August 2000, and see Nancy Sandars' recollections in Archaeology International 1999-2000,11-12. Zeuner's lifelong interest in animal domestication culminated in 1963 in the publication by Hutchinson of his final book, A history of domesticated animals.

6. Letter dated 4 October 2000, and see Rachel Maxwell-Hyslop's reminiscences in Archaeology International 1999-2000, 9-10.

7. See V. Gordon Childe, "Archaeology as a social science: inaugural lecture", Third Annual Report University of London Institute of Archaeology, 49-60, 1947.

8. Sir Mortimer Wheeler, Archaeology from the Earth, 2 (Oxford: Oxford University Press, 1954).

9. The examination papers for the diploma were signed by Gordon Childe, Kathleen Kenyon, Frederick Zeuner and Christopher Hawkes.

10. The thesis was entitled "A Roman military problem: a re-assessment of Wales and the southern Pennines in the second century". Most of it was later published in book form as Britons and the Romanarmy (London: Gregg Press, 1964), with a foreword by Mortimer Wheeler. 